\title{
PROGRESS IN KNOWLEDGE OF MICROSCOPIC TUBERCULOSIS DIAGNOSIS LABORATORY TRAINING PARTICIPANTS
}

\author{
Silvia Sutandhio ${ }^{1)}$, Ni Made Mertaniasih ${ }^{2)}$, Eko Budi Koendhori ${ }^{2)}$, Deby Kusumaningrum ${ }^{2)}$, \\ Titiek Sulistyowati ${ }^{3)}$, Lindawati Alimsardjono ${ }^{2)}$, Pepy Dwi Endraswari ${ }^{2)}$, Manik Retno \\ Wahyunitisari $^{2)}$, Rebekah Juniati Setiabudi ${ }^{2)}$
}

\begin{abstract}
Indonesia is the second highest tuberculosis (TB)-burden country in the world. TB affects men and women in productive ages. Early and accurate diagnosis of TB is crucial in TB management because it allows prompt treatment with appropriate regimen. Sputum smear microscopy is the most common method used in resource-limited laboratories. The aim of this study is to assess whether adult learning method with student-centered approach can improve knowledge in laboratory techniques in microscopic TB diagnosis. It was a quasi experimental research with one group pretest and posttest design. Pretest was conducted before the training started. During the training, participants attended lectures, discussion sessions, and hands-on laboratory activities. After training, participants were asked to respond to posttest. There were 33 participants of this training $(n=33)$. Paired t-test analysis showed significant difference between pretest and posttest scores $\left(p=6.5 \times 10^{-9}\right)$. Variance between pretest scores was 4.00 and variance between posttest scores were 1.34. Pearson correlation coefficient was 0.45. Regardless their level of knowledge before training, participants could achieve relatively equivalent results after training. Significant difference between pre- and posttraining test scores indicated that the learning method was effective and the training could improve participants knowledge in laboratory techniques in microscopic TB diagnosis.
\end{abstract}

Keywords: Tuberculosis, Knowledge, Pretest, Posttest, Laboratory Training, Sputum Smear Microscopy

\begin{abstract}
ABSTRAK
Indonesia adalah negara kedua dengan beban tuberkulosis (TB) tertinggi di dunia. TB menyerang laki-laki dan perempuan usia produktif. Diagnosis dini dan akurat berperan dalam manajemen TB karena menentukan terapi dengan regimen yang tepat. Pemeriksaan sputum mikroskopik adalah metode yang paling sering digunakan di laboratorium mikrobiologi sederhana. Tujuan penelitian ini adalah mengetahui metode pembelajaran orang dewasa dengan berpusat pada siswa dapat meningkatkan pengetahuan tentang teknik laboratoris pada
\end{abstract}


diagnosis TB mikroskopik. Penelitian ini bersifat quasi eksperimental dengan rancangan satu grup pretest dan posttest. Pretest dilaksanakan sebelum pelatihan dimulai. Selama pelatihan, peserta mengikuti kuliah, sesi diskusi, dan kegiatan hands-on di laboratorium. Setelah pelatihan, peserta diminta mengerjakan posttest. Ada 33 orang peserta pelatihan $(n=33)$. Uji $t$ berpasangan menunjukkan perbedaan signifikan antara nilai pretest dan posttest $\left(\mathrm{p}=6,5 \times 10^{-9}\right)$. Variasi nilai pretest sebesar 4,00 dan variasi nilai posttest sebesar 1,34. Koefisien korelasi Pearson sebesar 0,45. Meskipun memiliki tingkat pengetahuan awal yang berbeda, peserta dapat memperoleh nilai yang relatif setara setelah mengikuti pelatihan. Perbedaan signifikan antara nilai pre- dan posttest mengindikasikan bahwa metode pembelajaran sudah efektif dan pelatihan dapat membantu meningkatkan pengetahuan peserta dalam teknik laboratoris pada diagnosis TB mikroskopik.

Kata Kunci: Tuberkulosis, Pengetahuan, Pretest, Posttest, Pelatihan Laboratoris, Pemeriksaan Sputum Mikroskopik

1) Faculty of Medicine, Widya Mandala Catholic University Surabaya.Correspondence address: doctorsutandhio@gmail.com. 2) Faculty of Medicine, Universitas Airlangga - Dr. Soetomo General Hospital Surabaya. 3) Balai Besar Laboratorium Kesehatan Surabaya.

\section{BACKGROUND}

Indonesia is ranked $4^{\text {th }}$ most populated country after China, India, and United States of America. Population pyramid of Indonesia is bell-shaped, which is typical for developing countries (Figure $1) .1,2$
Indonesia is known as the second highest tuberculosis (TB)-burden country in the world. TB affects mostly men, and in fewer number, women in productive ages (Figure 2). Thus, TB does not only deter health, but also social and economic aspect of the nation. ${ }^{3}$

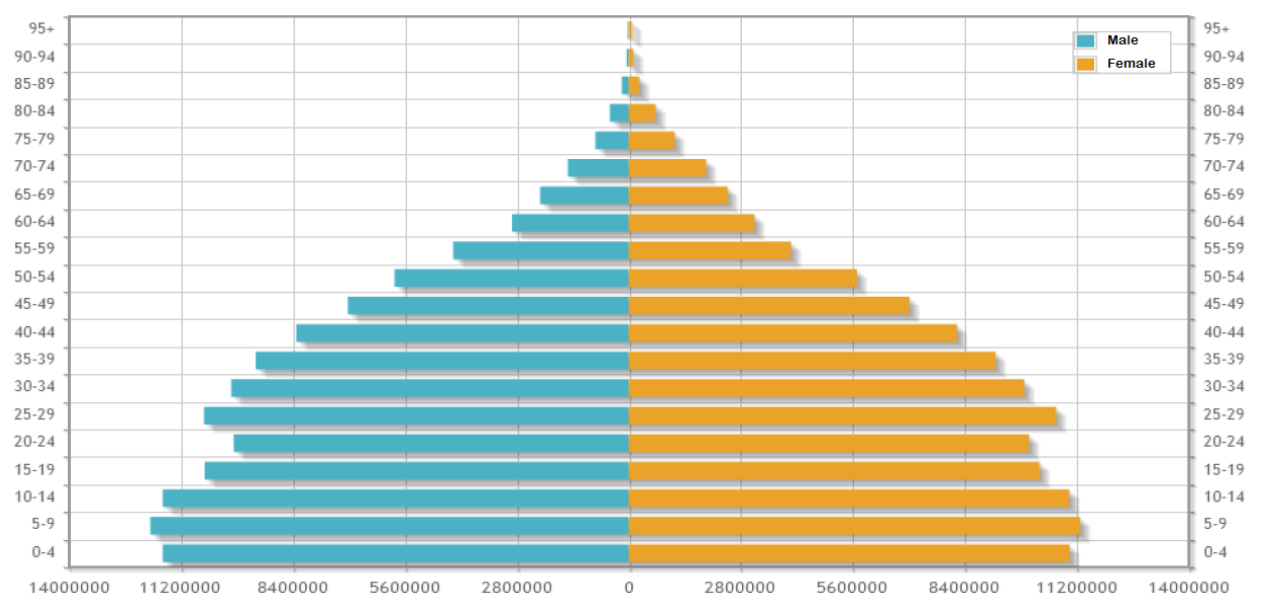


Figure 1. Population Pyramid of Indonesia ${ }^{1}$

Vertical axis: age group; Horizontal axis: number of population

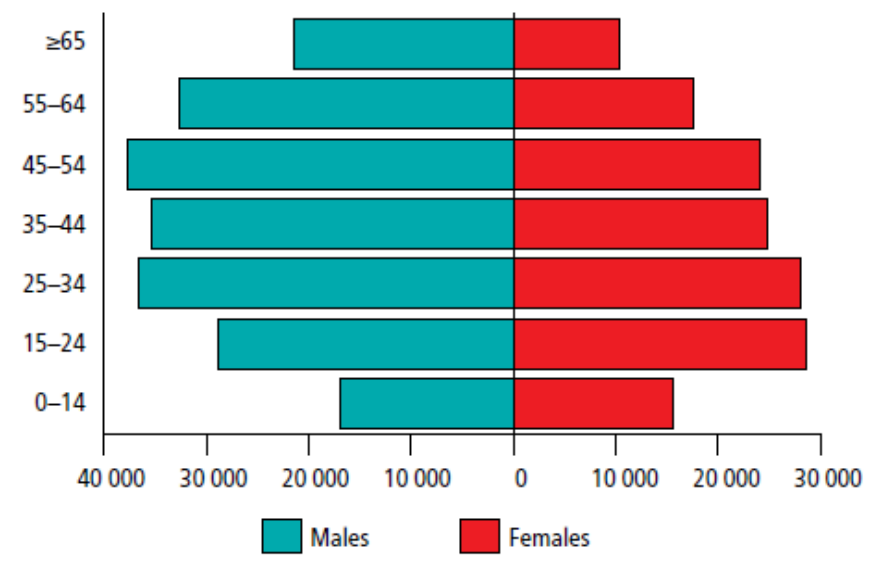

Figure 2. Notified Cases of TB by Age-group and $\mathrm{Sex}^{3}$

Vertical axis: age group; Horizontal axis: number of cases

Early and accurate diagnosis of TB is crucial in management of TB because it allows prompt treatment with appropriate regimen. Sputum smear microscopy is the most common method used in resourcelimited laboratories. ${ }^{4,5}$

The aim of this study is to assess whether adult learning method with student-centered approach can improve knowledge in laboratory techniques in microscopic TB diagnosis. Participants of this training are medical doctors and laboratory technicians.

\section{METHOD}

It was a quasi experimental research with one group pretest and posttest design. Pretest was conducted before the training started. Pretest consisted of 10 questions about laboratory techniques in $\mathrm{TB}$ diagnosis. During the training, participants attended lectures, discussion sessions, and hands-on laboratory activities (Table 1). The training took place in Clinical Microbiology Laboratory of Faculty of Medicine Universitas Airlangga Surabaya on August $5^{\text {th }}$ and $6^{\text {th }}$, 2017. After the training, participants were asked to respond to posttest with similar questions. There were 33 participants in this training $(n=33)$. However, since the identities of pre- and posttest respondents were encoded, researchers could not compare test results based on respondents' background.

\section{RESULT}

The data of pretest and posttest was analyzed using paired t-test and the results are listed in Table 2. 
Table 1. Event Rundown

\begin{tabular}{|c|c|c|}
\hline Time & Event & Provider(s) \\
\hline \multicolumn{3}{|l|}{ Day 1} \\
\hline 07.30-08.00 & Opening Ceremony & Organizing Committee \\
\hline 08.00-08.10 & Pretest & Organizing Committee \\
\hline 08.10-08.50 & Lecture: National Program of TB Eradication & Lecturer \\
\hline 08.50-09.30 & Lecture: Update on TB Diagnosis & Lecturer \\
\hline 09.30-10.00 & Coffee break & Organizing Committee \\
\hline $10.00-10.40$ & Lecture: Collection of Sputum Specimens & Lecturer \\
\hline $10.40-11.20$ & Lecture: Microscope Use and Maintenance & Lecturer \\
\hline $11.20-12.40$ & Lecture: Microscopic TB Examination & Lecturer \\
\hline $12.40-13.30$ & Discussion Session and Lunch & Organizing Committee \\
\hline $13.30-14.00$ & Lab session: Safety Precautions in TB laboratory & Tutors \\
\hline \multirow[t]{2}{*}{$14.00-16.00$} & Lab session: Practice of Sputum Smearing and & Tutors \\
\hline & Staining; Result Interpretations & \\
\hline \multicolumn{3}{|l|}{ Day 2} \\
\hline \multirow[t]{2}{*}{ 08.00-08.40 } & Lecture: Internal Quality Control of Microscopic TB & Lecturer \\
\hline & Laboratory & \\
\hline \multirow[t]{2}{*}{ 08.40-09.20 } & Lecture: External Quality Control of Microscopic TB & Lecturer \\
\hline & Laboratory & \\
\hline $09.20-09.50$ & Coffee Break & Organizing Committee \\
\hline $09.50-10.30$ & Lecture: Result Documentation and Reporting & Lecturer \\
\hline \multirow[t]{2}{*}{$10.30-12.30$} & Lab session: Practice of Sputum Smearing and & Tutors \\
\hline & Staining; Result Interpretations & \\
\hline $12.30-13.30$ & Discussion Session and Lunch & Organizing Committee \\
\hline \multirow[t]{2}{*}{$13.30-15.30$} & Lab session: Practice of Sputum Smearing and & Tutors \\
\hline & Staining; Result Interpretations & \\
\hline $15.30-15.40$ & Posttest & Organizing Committee \\
\hline $15.40-16.00$ & Closing ceremony & Organizing Committee \\
\hline
\end{tabular}


Table 2. t-Test: Paired Two Sample for Means

\begin{tabular}{lcc}
\hline & Pretest score & Posttest score \\
\hline Mean & 6.242424242 & 8.696969697 \\
Variance & 4.001893939 & 1.34280303 \\
Observations & 33 & 33 \\
\hline Pearson Correlation & 0.450580768 \\
Hypothesized Mean Difference & 0 \\
Degree of freedom & 32 \\
t Stat & -7.814605737 \\
P(T<=t) one-tail & $3.24756 \times 10^{-9}$ \\
t Critical one-tail & 1.693888703 \\
P $(T<=t)$ two-tail & $6.49512 \times 10^{-9}$ \\
t Critical two-tail & 2.036933334 \\
\hline
\end{tabular}

Pretest mean was 6.24 and posttest mean was 8.70 , indicating increase in posttraining knowledge. Variance between pretest scores was 4.00 and variance between posttest scores was 1.34, indicating that participants knowledge before training varied greatly, but it became more equivalent after training. Pearson correlation value was 0.45 , indicating moderate degree of correlation between pretest and posttest. Result of t Stat was smaller than $t$ Critical two-tail with $\mathrm{p}$ value $6.5 \times 10^{-9} \quad(\mathrm{p}<0.05)$, indicating significant difference between pretest and posttest scores.

\section{DISCUSSION}

Indonesia is the largest archipelago country in the world with total 240 millions inhabitants. Most of its population (57.5\%) lives in Java island. The population density and economic disparities between provinces had contributed in spread of TB. In 2016, estimated incidence of TB in Indonesia was $>1$ million cases per year; estimated incidence of TB in people living with HIV was 45,000 cases per year; and estimated incidence of multi-drug resistant (MDR) TB was 32,000 cases per year. ${ }^{1,3}$

Diagnosis of TB can be made based on clinical presentations or laboratory examinations. There are several methods of laboratory diagnosis of $\mathrm{TB}$, i.e., rapid molecular tests, sputum smear microscopy, and culture-based methods. . $^{3,4,6-8}$

Sputum smear analysis requires serial sputum specimens, i.e., one specimen is taken on spot and the second specimen is sputum on early morning. The sensitivity of this method may vary from $20 \%$ to $80 \%$ (depending on specimen quality, smearing and staining process, and competency of examiner in detecting acid-fast bacilli), and 
Sutandhio S, Mertaniasih NM, Koendhori EB, Kusumaningrum D, Sulistyowati T, Alimsardjono, L, Endrawari PD, Wahyunitisari MR, Setiabudi RJ

requires at least $5 \times 10^{3}$ bacilli per $\mathrm{ml}$ of sputum. This method is also less sensitive compared to simplified molecular procedure that are adaptable in routine settings. Despite its inferiority, sputum smear microscopy is the most common method used in resource-limited laboratories in high TB prevalence countries due to its speed, easy performance, and low cost. To avoid low sensitivity of this method, effective External Quality Assurance (EQA) according to World Health Organization (WHO) standards is needed. However, compliance to EQA programs can be difficult in resorce-limited laboratory setting. ${ }^{4,8-13}$

When a person with little knowledge of microscopic TB diagnosis techniques work in laboratory, he/she may give false results of TB diagnosis due to human factors. Therefore, it is imperative that government provide adequate training for laboratory technicians and their supervisors (medical doctors). ${ }^{13,14}$

This laboratory training in microscopic TB diagnosis rundown is listed in Table 2. The classroom seat formation was in comfortable space, where every three to four participants shared a long desk, which enabled them to listen to the lecturers during lectures, and discuss with each other in discussion sessions. In laboratory, participants were divided into groups where every group consisted of eight to nine participants to maintain learning environment. Each group was accompanied by a national-approved tutor.

Method of learning process for this training was adult learning method with student-centered approach. Participants were given printed module of sputum smear preparation when they registered for training. Reading module and listening to lectures were meant to prepare participants for laboratory works. Lectures were made interactive, so that participants could share their experiences, or, to some extent, seek answers to the problems they faced in their workplaces. Discussion sessions were meant to increase retention of knowledge. Lastly, participants practiced their knowledge in laboratory sessions. The whole process was repeated on the second day of training. ${ }^{15-18}$

Well-prepared participants were more likely to successfully acquire skills and gain maximum possible benefit from the laboratory learning process. Eventually, participants retention of knowledge would be greatest when they applied their knowledge or taught other laboratory technicians in their own laboratories. ${ }^{19-21}$ 
In this research, variance of participants pretest scores was 4.00 which indicate that their knowledge varied greatly before training. However, participants posttest mean was 8.70 and the variance was 1.34, which was more equivalent compared to their pretests variance result. With Pearson correlation coefficient 0.45 , we can conlude that regardless their level of knowledge before training, participants can achieve relatively equivalent results after training. ${ }^{22}$

Significant difference $\quad(\mathrm{p}<0.05)$ between pre- and posttest scores indicated that the learning method was effective and that the training was very helpful in improving participants knowledge in microscopic laboratory techniques. Higher knowledge would result in better performance in laboratory. Therefore, providing adult learning method with student-centered approach training on laboratory techniques may improve sensitivity of sputum smear analysis in TB diagnosis.

\section{CONCLUSIONS}

Adult learning method with studentcentered approach can improve participants knowledge in laboratory techniques in microscopic TB diagnosis. Regardless their level of knowledge before training, participants can achieve relatively equivalent results after training.

\section{ACKNOWLEDGEMENT}

The authors thank Dicky Bagus Widhyatmoko, MD., Elita Devina, MD., Dewi Retnoningsih, MD., Neneng Dewi Kurniati, MD., Dian Rachmawati, MD., Lidya Handayani, MD., and Novita Arbianti, MD., for their cooperation in organizing this training, as well as all training participants who have become our respondents in this study.

\section{REFERENCES}

1. BPS. Sensus Penduduk. 2010. Retrieved March 23, 2018 from www.bps.go.id

2. UN. World Population Prospects. New York: United Nations. 2017

3. WHO. Global Tuberculosis Report. 2017. Retrieved March 23, 2018 from www.who.int/tb/data

4. Parsons LM, Á Somoskövi, C Gutierrez, E Lee, CN Paramasivan, A Abimiku, et al. Laboratory Diagnosis of Tuberculosis in Resource-Poor Countries: Challenges and Opportunities. 2011. Clin Microbiol Rev 24:314-350 doi:10.1128/CMR.00059-10

5. Khosravi AD, $\mathrm{M}$ Mehdinejad, A Mozzafari, M Hashemzadeh. Study of Sputum and Bronchoscopic Lavage for Acid-Fast Bacilli in Patients with Pulmonary Infections. 2010. Afr. J. Microbiol. Res. 4(22), pp. 2414-2417. 
Sutandhio S, Mertaniasih NM, Koendhori EB, Kusumaningrum D, Sulistyowati T, Alimsardjono, L, Endrawari PD, Wahyunitisari MR, Setiabudi RJ

6. Murphy ME, PJP Phillips, CM Mendel, 2014 7:295. doi:10.1186/1756-0500-7E Bongard, ALC Bateson, R Hunt, et 295

al. Spot Sputum Samples Are At Least As Good As Early Morning Samples for Identifying Mycobacterium tuberculosis. BMC Medicine (2017) 15:192. DOI 10.1186/s12916-0170947-9

7. Cuevas LE, N Al-Sonboli, L Lawson, MA Yassin, I Arbide, N Al-Aghbari, et al. LED Fluorescence Microscopy for the Diagnosis of Pulmonary Tuberculosis: A MultiCountry CrossSectional Evaluation. 2011. PLoS Med 8(7): e1001057. doi:10.1371/journal.pmed.1001057

8. Ani A, Y Isah, R Pwol, C Lekuk, T Ashi-Sulaiman, M Akindgh, et al. Detection of Mycobacterium tuberculosis by Rapid Molecular Methods Augments Acid-Fast Bacilli (AFB) Smear Microscopy in a NonCulture Tuberculosis Laboratory. 2015. Afr. J. Microbiol. Res. 9(13), pp. 960964. doi: 10.5897/AJMR2014.7358

9. Mekonnen A. Smear-Positive Pulmonary Tuberculosis and AFB Examination Practices According to the Standard Checklist of WHO's Tuberculosis Laboratory Assessment Tool in Three Governmental Hospitals, Eastern Ethiopia. BMC Research Notes 
15. Dunlosky J, KA Rawson, EJ Marsh, MJ Nathan, DT Willingham. Improving Students' Learning with Effective Learning Techniques: Promising Directions from Cognitive and Educational Psychology. 2013. Psychological Science in the Public Interest 14(1) 4-58. DOI: $10.1177 / 1529100612453266$

16. Gitterman A. Interactive Andragogy: Principles, Methods, and Skills. Journal of Teaching in Social Work, Vol. $24(3 / 4)$ 2004. doi:10.1300/J067v24n03_07

17. Karge BD, KM Phillips, T Jessee, M McCabe. Effective Strategies for Engaging Adult Learners. 2011. Journal of College Teaching and Learning Vol. 8, No. 12. doi:10.19030/tlc.v8i12.6621

18. Mba SI, II Uba. The Effect of Laboratory Works in Teaching and Learning of Physics in Onitsha North, Anambre State. Journal of Science and Arts Year 12, No. 1(18), pp. 75-84, 2012.

19. Gregory S-J and G Di Trapani. A Blended Learning Approach to Laboratory Preparation. International Journal of Innovation in Science and
Mathematics Education, 20(1), 56-70, 2012.

20. O'Brien $\mathrm{G}$ and $\mathrm{M}$ Cameron. Prelaboratory Activities to Enhance the Laboratory Learning Experience. In K. Placing (Ed.) Proceedings of the Visualisation for Concept Development Symposium, (pp. 80-85). 2008. Sydney: UniServe Science. Retrieved April 18, 2018, from http://science.uniserve.edu.au/pubs/pro cs/2008/index.html

21. Dresner M, C de Rivera, KK Fuccillo, $\mathrm{H}$ Chang. Improving Higher-Order Thinking and Knowledge Retention in Environmental Science Teaching. BioScience, Vol. 64, Issue 1, 1 January 2014, pp. 40-48. doi:10.1093/biosci/bit005

22. Sutandhio S, NM Mertaniasih, EB Koendhori, D Kusumaningrum, T Sulistyowati, L Alimsardjono, et al. Progress in Knowledge of Microscopic Tuberculosis Diagnosis Laboratory Training Participants. e-Poster session presented at: Asia Pacific Conference on Problem Based Learning in Health Sciences and Higher Education; 2018 August 3-5; Surabaya. 